\title{
Avaliação do Conceito de Evolução nos Livros Didáticos
}

\author{
LUZIA MARTA BELLINI \\ Professora Doutora do Departamento de Fundamentos da Educação da \\ Universidade Estadual de Maringá \\ martabellini@uol.com.br
}

\begin{abstract}
Resumo
O artigo apresenta considerações sobre a teoria da argumentação e sobre o papel das metáforas na passagem da linguagem das ciências para a linguagem dos livros didáticos. Analisa o conceito de evolução em 12 livros didáticos e indica que as metáforas pedagógicas presentes nos textos reduzem a evolução a noções não-científicas.

Palavras-chave: teoria da argumentação, metáforas pedagógicas, conceito de evolução nos livros didáticos.

\section{Resumen}

El artículo presenta consideraciones sobre la teoria de la argumentación y sobre el papel de las metáforas en el pasaje del lenguage de las ciências para el lenguage de los libros didácticos. Analiza el concepto de evolución en 12 libros didácticos e indica que las metáforas pedagógicas presentes en los textos reducen la evolución a nociones no científicas. Palabras-clave: teoria de la argumentación, metáforas pedagógicas, concepto de la evolución en los libros didácticos.
\end{abstract}

\begin{abstract}
This article puts forward some considerations on the theory of argumentation and the role metaphors play in passing from the language of science to the language in textbooks. It analyses the concept of evolution in twelve textbooks and argues that pedagogical metaphors in the texts restrict evolution to non-scientific notions.

Key words: argumentation theory, pedagogical metaphors, concept of evolution in textbooks.
\end{abstract}




\section{INTRODUÇÃO}

Como se dá a transposição das idéias, das noções e dos conceitos das ciências para os livros didáticos? Para muitos estudiosos esta passagem estabelece alguns problemas que merecem avaliações metodológicas. Pretto (1985) e Bizzo (2000) indicam erros conceituais, alguns demasiadamente grosseiros, sem qualquer conexão com o vocabulário das ciências. Daisy Lara de Oliveira (1992) aponta, nos livros didáticos de ciências, a visão antropocêntrica da natureza que orienta a classificação dos seres vivos em úteis, nocivos, selvagens, domésticos ou outras categorias como animais importantes, devoradores, gangues, ovelhas negras. Aponta, também, para o desconhecimento da biologia evolutiva que faz com que os autores de livros didáticos deturpem as explicações paleontológicas em prol de supostas histórias dos animais. Renato José de Oliveira (1992) discute duas concepções básicas que aparecem nos livros de ciências, para ele, equivocadas. A primeira, romântica, mostra a ciência como uma história romântica: com começo, meio e fim, certinha e bem sucedida. A segunda concepção é a de solilóquio, uma prática muito comum em sala de aula. Trata-se da aula em que o professor conversa consigo mesmo. Ou seja, ele conta, para si, as histórias das ciências ou as suas definições, repetindo o que já sabe.

Os problemas apresentados por estes autores denunciam que a comunicação didática das ciências padece de muitos males: distorções nos enunciados, interpretações errôneas dos conceitos científicos e concepções estranhas às ciências. De tudo isso, podemos afirmar que resta para os alunos um universo científico sem a instrumentação intelectual própria do mundo das ciências, os problemas, as hipóteses de investigação, um vocabulário específico com conceitos pertinentes à área que se estuda.

Neste artigo, discutiremos a passagem do conhecimento científico para a situação de difusão ou de ensino, investigando o conceito de evolução, a partir da teoria da argumentação enfatizada por Contenças (1999), no estudo sobre a eficácia das metáforas na genética.

\section{FUNDAMENTAÇÃO TEÓRICA}

\section{A teoria da argumentação: algumas considerações}

Se tomarmos estudos sobre a argumentação, vamos percorrer um caminho que nos leva à dinâmica da comunicação. Breton (1999) diz que a argumentação está na base de nossa atividade social e é de natureza 
discursiva. A argumentação está na nossa vida cotidiana e é ela que nos permite expressar e defender pontos de vista diferentes ou divergentes com a finalidade de convencer o interlocutor. Mesmo em situação de monólogo no contexto das palestras, ou da leitura de livros - situações presentes no cotidiano das pessoas - nos engajamos na argumentação. Trata-se, aí, de diálogo das argumentações do livro. O diálogo se realiza pela presença das idéias/argumentos do livro - interlocutor imaginário - que pretende nos convencer. Os leitores podem ser convencidos ou elaborar contraargumentos. São confrontos entre pontos de vista e entre indivíduos. A argumentação define-se como atividade social de natureza dialógica.

$\mathrm{Na}$ sala de aula, quando os professores, por meio do livro didático, adequam os conhecimentos e os argumentos científicos aos estudantes, eles estão agindo como retóricos. Esse procedimento de adequação pode ser examinado com base nas figuras de pensamento que coordenam e condensam os significados dos livros. Isto é, os procedimentos dizem respeito à melhor apresentação do saber feita pelo professor aos alunos (auditório). Se o professor ficar distante das figuras que apresentam o universo conceitual e distante do mundo afetivo do aluno, menor será o espaço para a negociação de significados com os aprendizes, tanto na retórica, em geral, quanto da retórica escolar, em particular.

Breton (1999, p.19) diz que "saber argumentar não é um luxo, mas uma necessidade". Pergunta o autor:

Não saber argumentar não seria, aliás, uma das grandes causas recorrentes da desigualdade cultural que se sobrepõe às tradicionais desigualdades sociais $e$ econômicas, reforçando-as? Não saber tomar a palavra para confrontar não seria, no final das contas, uma das grandes causas da exclusão? Uma sociedade que não propõe a todos os seus membros os meios para serem cidadãos, isto é, para terem uma verdadeira competência ao tomar a palavra, seria verdadeiramente democrática?

A argumentação é definida como o campo que "pertence à família das ações humanas que têm como objetivo convencer". Os meios são extremamente variados e colocam "em ação procedimentos complexos que utilizam toda a riqueza de comportamentos humanos". Tomemos como exemplo um ministro falando da necessidade de manter a taxa de juros do Banco Central de seu país, indicando em seu argumento que as estatísticas mostram que o país está em desenvolvimento econômico. Temos, nesse caso, um duplo argumento: o estatístico e o de apelo à autoridade (Breton, 1999).

Breton apresenta a retórica de Chäim Perelman e L. OlbrechtsTyteca, que marcou uma reviravolta no campo da argumentação ao 
retomar e revitalizar a retórica de Aristóteles. Sobre o trabalho de Perelman, escreveu Breton:

Para Perelman, um raciocínio pode convencer sem ser cálculo, pode ser rigoroso sem ser "científico". Ele define, então, a argumentação como "o estudo das técnicas discursivas que permitem provocar ou aumentar a adesão das pessoas às teses que são apresentadas para seu assentimento" (1970, p. 5). Devemos a Perelman a verdadeira renovação do interesse pela argumentação. $(1999$, p.19)

A argumentação supõe o orador (ethos), os argumentos (logos) e o auditório (pathos), três partes que compõem o triângulo argumentativo. $\mathrm{O}$ orador é aquele que argumenta para si mesmo ou para outros.

Ele dispõe de uma opinião - argumento - com o qual elabora seu raciocínio pela palavra, imagem, bilhete, carta ou outro meio. O auditório pode ser "uma pessoa, um público, um conjunto de públicos ou até, em um caso extremo, do próprio orador quando ele procura se "autoconvencer". (Breton, 1999, p.29)

O conjunto de opiniões, valores, julgamentos é partilhado por um auditório que vai, ou não, aceitar o conjunto de argumentos.

Na dinâmica argumentativa não se trata de convencer um auditório a qualquer custo, de dizer: vamos convencer. A questão é pensar como conseguimos a adesão do auditório. Argumentos de sedução, de autoridade podem convencer a qualquer custo, mas, nesses casos, temos de supor a manipulação do pensamento ou os excessos que ocorrem na argumentação. Para sair deste impasse, dois níveis de argumentos são evidenciados: o nível do conteúdo do argumento, das opiniões em si mesmas e o nível do molde argumentativo que dá forma à tese proposta pelo orador (Breton, 1999). Segundo esse autor, são dados diferentes nomes a esses moldes: argumento quase lógico (verossímil), argumento ad hominem ou argumento por exemplo. Argumento é também usado para designar o conjunto constituído pelo argumento e seu conteúdo particular (Breton, 1999).

Há razões para se aderir a uma argumentação, e isso passa por uma fase essencial que é chamada de enquadramento do real. A pergunta é: como fazer para que um argumento seja aceito? Breton fala em conhecer pelo menos três razões para que ocorra a adesão: a ressonância, a curiosidade e o interesse. A ressonância torna apresentável uma novidade, a curiosidade nos leva a ter boa vontade com um novo fato, e o interesse é um vetor de aceitação. A partir daí, definimos o enquadramento do real, passo que permite pensar uma ordem de mundo a partilhar com o auditório. Temos, nesse caminho, categorias de argumentos: de autoridade, 
de confiança, de competência, de experiência de testemunho. Temos argumentos dedutivos e argumentos que recorrem às analogias.

As analogias, de interesse nosso neste artigo, são fontes de recursos para as comparações. Entre as analogias, uma especial é a metáfora. Raciocinar por analogia é construir uma estrutura real por uma semelhança de relações (Breton, 1999).

Reboul nos lembra que raciocinar por analogias é "construir uma estrutura do real" graças a "uma semelhança de relações" como no exemplo clássico que diz que "o pai é para seu filho o que Deus é para o homem" em que supõe aceito o acordo sobre as relações que o homem deve manter com Deus: respeito, submissão, reconhecimento da autoridade (situamo-nos, evidentemente, no contexto de um auditório particular). (Breton, 1999, p.137)

As metáforas não são meras figuras de estilo que ornamentam um discurso; são figuras argumentativas, e, como tal, têm uma função cognitiva:

As figuras argumentativas têm uma função cognitiva, o que, em nossos dias, têm ficado cada vez mais presente aos semioticistas, lingüistas e filósofos da linguagem, por exemplo. Estes especialistas consideram que as metáforas, metonimias e sinédoques são esquemas, ou formas, cognitivas que "carregam" sentido de um contexto para outro. Estas investigações têm orientado a análise de discurso, com base na lingüística funcional, ou de orientação cognitiva, devida a George Lakoff (1981, 1987), Mack Johnson (1987) e Eve Sweetser (1991). (Mazzotti, Oliveira, 1999, p.7)

No conhecimento científico as analogias constituem importantes figuras de argumento. Contenças (1999), analisando o alcance das metáforas na genética, salienta a sua função heurística e cognitiva na elaboração dos conceitos da genética. Outro estudo interessante acerca do papel das metáforas nos argumentos científicos, também na genética, é o de Robert Pollack (1997). Os dois autores trazem as expressões metafóricas constitutivas da explicação teórica na área.

\section{A linguagem científica: dos enunciados lógicos às metáforas}

A comunicação das ciências constitui, hoje, uma fonte de novidades metodológicas. No empirismo clássico a linguagem científica traduz os procedimentos, as idéias ou os fatos científicos por meio de idéias como unidades do pensamento que, podemos dizer, são os enunciados. No empirismo clássico, estabeleceu-se a comunicação pelos enunciados, 
rigorosamente fundamentados na coleta de dados. No empirismo lógico, a comunicação foi estabelecida recorrendo-se, de um lado, à observação e coleta de dados, e, de outro, à lógica (Contenças, 1999). O neopositivismo postulou os enunciados da experiência sobre os objetos de qualquer espécie e os enunciados analíticos da lógica e das matemáticas como recurso para produzir seu vocabulário. Fez parte do projeto do positivismo lógico tratar a teoria científica como um conjunto de enunciados sistematicamente relacionados que incluem alguma generalização, como uma lei, sempre a partir de dados empíricos (Contenças, 1999).

A crítica dessa concepção de ciência partiu de pensadores que contestaram a filosofia normativa do neopositivismo. Desde a década de 50 do século XX, Khun, Popper e outros como Perelman, Olbrechts-Tyteca e Habermas, admitem que não existe uma só forma de justificação, seja teórica ou empírica; há muitos critérios de avaliação das teorias (Chalmers, 1993; Contenças, 1999).

Após a década de 50, houve o reconhecimento de que o conhecimento científico não podia se desligar da linguagem em que era apresentado. Se para os positivistas lógicos as analogias, assim como os modelos, somente podiam ter um papel heurístico nos processos de construção das teorias, sem valor para a estrutura lógica e da explicação teórica, na prática comunicativa da ciência das novas correntes, como a dos estudos de Boyd, Ricoeur, Black, Hesse, Perelman, Olbrechts-Tyteca e Marchal, as expressões figurativas ou figuras de sentido, entre elas a metáfora, são parte do discurso científico e do contexto da descoberta científica, da função heurística da elaboração de hipóteses e dos procedimentos de investigação (Contenças, 1999).

As metáforas são elementos constitutivos das teorias científicas que ampliam os conceitos e o vocabulário das teorias; não são apenas formas de comunicação dos pesquisadores, são sempre novas significações. Darwin, por exemplo, é lembrado por Stephen Jay Gould como o mestre das metáforas. O conceito de seleção natural de Darwin foi elaborado a partir da analogia com a seleção artificial feita por criadores de animais e por agricultores. Na genética, o papel das metáforas foi o de abertura das teorias (Pollack, 1997; Contenças, 1999).

O termo código genético trouxe para o público um conhecimento específico em uma linguagem mais ampla. As palavras cópia, código e informação, mensageiro estrutural, transcrição, cadeia de aminoácidos são derivadas de dois conjuntos metafóricos que se vinculam na linguagem da genética: um é referente à teoria da informação e da cibernética e o outro referente aos termos da própria lingüística. O modelo teórico da genética deve muito à introdução das metáforas que criou uma nova linguagem e 
também a um novo domínio de aplicação; são, assim, argumentos essenciais para a estrutura da teoria ou modelos (Pollack, 1997; Contenças, 1999).

A genética é, por excelência, uma ciência que se apresenta por belas metáforas. Pollack, geneticista que se encantou com a vida das bactérias, descreveu a biologia molecular como um projeto que visa a entender como nossos corpos fazem a leitura dos textos químicos que existem nas células, o DNA. A metáfora do DNA como uma enciclopédia, dos cromossomos como os volumes, das quatro bases como grupos de frases e dos genes como as frases podem nos ajudar a aprender como o DNA copia a si mesmo tão bem, escreveu Pollack (1997).

A metáfora da dupla hélice não só foi aceita para a explicação da estrutura do DNA como também levou muitos cientistas a buscar respostas de diversos aspectos da genética, entre eles o funcionamento da reprodução da molécula de DNA. O modelo da dupla hélice levantou questões em torno do significado do código: como se processavam as informações? Como eram transportadas e manifestadas na célula?

De 1953 a 1966, os cientistas tentaram responder às questões do processo do código. O modelo permitiu esclarecer o mecanismo de replicação por Meselson e Stahl, em 1958, pois "se se admitia que duas cadeias de DNA eram o molde para a síntese de novas cadeias, eram possíveis, teoricamente, várias hipóteses. A replicação só podia ser conservativa" (Contenças, 1999, p. 107).

Em 1960, François Jacob e Jacques Monod, ao descreverem a síntese protéica, afirmaram que essa síntese envolvia algo que chamaram de mensageiro. Em 1961, outras equipes de geneticistas identificaram o que chamaram de RNA. Nesses anos, instigados pelo modelo de dupla hélice e a ele respondendo, os geneticistas elaboraram a explicação do que foi chamado de código genético, RNA mensageiro e, finalmente, construíram o modelo para a duplicação do DNA e da síntese protéica. Uma história científica considerável e uma teoria que deve muito aos modelos e às metáforas (Pollack, 1997; Contenças, 1999).

\section{As metáforas nos livros didáticos: retórica pedagógica, retórica forçada}

A tarefa de ensinar requer a construção de argumentos científicos em outro nível, que chamamos de didático. Podemos dizer, então, que, nesse nível - no qual professores, livros didáticos e alunos se relacionam temos um procedimento retórico que pode ser analisado e conhecido. Contenças (1999) chama o nível didático de retórica forçada, pois é um 
nível que tem como objetivo entusiasmar, interessar e persuadir o aluno, mais do que introduzi-lo em uma ciência.

Nas aulas de ciências e nos manuais escolares, há uma reconstrução do saber produzido pelos cientistas e uma exigência forçada para reproduzir os movimentos já feitos pelos cientistas. A exigência da aprendizagem leva o professor a lançar mão tanto de metáforas constitutivas como das exegéticas ou pedagógicas. Empenhando-se nessa tarefa, ele recria suas próprias tarefas e, se o tema for complexo ou distante, o professor e os livros didáticos afastam-se dos conceitos originais o que pode produzir uma metaforização excessiva como estratégia pedagógica para convencer os leitores (Contenças, 1999).

A divulgação científica é feita por autores que não são ligados às atividades científicas, e como mediadores de saberes científicos se afastam dos argumentos originais e tomam as metáforas como recursos estilísticos e não como modelos (Contenças, 1999). A passagem feita dessa maneira produz um deslocamento das metáforas presentes como argumentos cognitivos para um discurso estilístico com conotações que facilitam a concepção antropomórfica, noções antievolucionistas em temas da evolução, idéias anticientíficas em modelos científicos. Nessa situação retórica, os temas científicos presentes nos livros didáticos ficam distantes da realidade dos alunos e podem produzir apenas a pseudo-adesão aos enunciados, ou seja, memorizam-se fórmulas, definições para passar nas avaliações, no vestibular, e como elas não têm sentido são esquecidas rapidamente.

\section{PROBLEMA E PROCEDIMENTOS METODOLÓGICOS}

\section{Evolução: o que há nos livros didáticos?}

No presente trabalho estabelecemos os seguintes problemas:

1) Como ocorre a transposição do conhecimento científico sobre o tema evolução para os manuais didáticos?

2) Quais as relações existentes entre os argumentos científicos e os didáticos?

3) Quais os problemas científicos que encontramos na passagem dos conceitos evolucionistas para os conceitos escolares?

Para aprofundar esses problemas tomamos de Gould (1987) suas avaliações a respeito das teorias de Lamarck, Darwin, Wallace, Haeckel em 
seu livro Darwin e os grandes enigmas da vida. Talvez uma das maiores contribuições para os problemas das interpretações de Darwin tenha sido a de Gould, visto que ele apresenta o tema evolução dando especial tratamento às questões evolucionistas do final do século XVIII e do século XIX. Além disso, Gould é bom retorista: seus argumentos e a apresentação das metáforas das teorias evolucionistas destinam-se a todo tipo de leitor, sobretudo se pensarmos que ele está debatendo com outro orador, o criacionista.

Nesse sentido, para a apresentação dos argumentos evolucionistas em livros didáticos, tomamos de Gould seu debate a favor do modelo de evolução que nasceu com Darwin. Utilizamos, também, o estudo de Jordanova (1984) sobre a construção da teoria de Lamarck durante os anos de 1779 a 1829, ano de sua morte. Nesse caminho, o texto de Roque (2002) marcou, efetivamente, o que intentávamos: analisar livros didáticos sob o ponto de vista das argumentações e suas analogias.

\section{Amostra dos livros didáticos}

Selecionamos 12 livros didáticos. O critério para essa seleção foi a disponibilidade dos livros, em uma pequena biblioteca de uma escola pública estadual, para consulta e estudo dos professores. São 7 livros para o ensino médio e 5 para o ensino fundamental; possivelmente dois deles são para as séries iniciais. Esses livros abrangem material didático para crianças de 7 anos até o jovem de 17.

\section{Método}

Dados os textos, efetuamos um recorte no tema evolução: selecionamos o tema introdução ao pensamento evolucionista, ou seja, as explicações das teorias básicas da evolução em Lamarck e Darwin. Enfatizamos: a) o conceito de evolução em Lamarck, b) o conceito de evolução em Darwin, c) as ilustrações e os exemplos de evolução decorrentes das idéias apresentadas nos livros. Apresentamos no quadro 1, a seguir, os argumentos dos textos didáticos utilizados: 


\begin{tabular}{|c|c|c|}
\hline Livro & Argumentos & Ênfase \\
\hline 1 & $\begin{array}{l}\text { A teoria da evolução supõe que: a) os seres vivos são passíveis de } \\
\text { modificações, que são alterações morfofisiológicas ao longo dos séculos (grifos } \\
\text { nossos); b) as espécies atuais originaram-se de outras preexistentes; c) a linha } \\
\text { evolutiva se desenvolve cada vez mais aprimorada e adaptada no decorrer do } \\
\text { processo de ajustamento e sobrevivência às condições existentes num } \\
\text { determinado ambiente. Entende-se por adaptação o conjunto de características } \\
\text { que contribuem para a sobrevivência (...). }\end{array}$ & $\begin{array}{l}\text { Tempo linear } \\
\text { analogia da } \\
\text { escada. }\end{array}$ \\
\hline 2 & $\begin{array}{l}\text { Chama-se seleção natural esse mecanismo de o ambiente selecionar os } \\
\text { organismos que nele vivem: os indivíduos portadores de características } \\
\text { "favoráveis" têm maior chance de sobrevivência e de deixar descendentes } \\
\text { férteis, enquanto os portadores de características "desfavoráveis" tendem a ser } \\
\text { eliminados, pois terão menores chances (grifos nossos). Evolução é o processo } \\
\text { de transformação pelo qual passam os seres vivos, incluindo a origem de } \\
\text { novas espécies e a extinção de outras através dos tempos. }\end{array}$ & $\begin{array}{l}\text { Evolução como } \\
\text { projeto do } \\
\text { melhor e para } \\
\text { melhor. }\end{array}$ \\
\hline 3 & O evolucionismo teve seu grande avanço realmente com Lamarck e Darwin. & $\begin{array}{l}\text { Analogia da } \\
\text { escada. }\end{array}$ \\
\hline 4 & $\begin{array}{l}\text { Evolução é o processo através do qual ocorrem as mudanças ou } \\
\text { transformações nos seres vivos ao longo do tempo, dando origem às espécies } \\
\text { novas. }\end{array}$ & $\begin{array}{l}\text { Analogia da } \\
\text { escada. }\end{array}$ \\
\hline 5 & $\begin{array}{l}\text { Evolução é o conjunto de mudanças graduais das características das } \\
\text { populações de seres vivos ao longo de gerações. (...) Dá o exemplo dos peixes e } \\
\text { dos anfíbios como possíveis descendentes de um grupo de peixes que alterado } \\
\text { pela falta de água pôde respirar também o oxigênio da atmosfera. } \\
\text { Lamarck: Lamarck afirmava que as partes do organismo mais usadas } \\
\text { desenvolviam-se mais que as outras; as partes não usadas acabavam } \\
\text { desaparecendo. Afirmava que as modificações ocorridas nos organismos eram } \\
\text { transmitidas aos descendentes. }\end{array}$ & $\begin{array}{l}\text { Tempo linear, } \\
\text { gradual. } \\
\text { Analogia da } \\
\text { escada. } \\
\text { Lei do uso e } \\
\text { desuso para } \\
\text { Lamarck. }\end{array}$ \\
\hline 6 & $\begin{array}{l}\text { Evolução: com as alterações que foram acontecendo no clima do nosso planeta, } \\
\text { os seres vivos tiveram que se adaptar ao novo ambiente. Os que não } \\
\text { conseguiram esta adaptação morreram, desaparecendo do planeta, como } \\
\text { provavelmente ocorreu com os dinossauros. Os seres vivos que se adaptaram, } \\
\text { evoluíram, isto é, foram sofrendo modificações em seu corpo. Portanto, os que } \\
\text { vivem hoje aqui já existiram há milhões de anos atrás. }\end{array}$ & $\begin{array}{l}\text { Tempo linear, } \\
\text { gradual. } \\
\text { Analogia da } \\
\text { escada. }\end{array}$ \\
\hline 7 & $\begin{array}{l}\text { O longo pescoço das girafas é intrigante. Por que ele é tão longo? Como os } \\
\text { cientistas acreditam que ele se desenvolveu? As girafas sempre tiveram } \\
\text { pescoço comprido? Que vantagem as girafas têm por possuir essa } \\
\text { característica? Igualmente curiosas são as inúmeras adaptações exibidas pelos } \\
\text { seres vivos e que os tornam aptos a sobreviver em seu ambiente específico. } \\
\text { Para você conhecer um pouco a história de seus ancestrais - pais, avós, bisavós } \\
\text { etc. -, certamente seriam muito úteis fotografias, roupas, objetos pessoais e } \\
\text { todo o tipo de registro escrito, como, por exemplo, cartas enviadas e recebidas } \\
\text { por eles etc. Da mesma maneira, para saber um pouco mais sobre a história do } \\
\text { passado do nosso planeta, os cientistas procuram esses documentos do } \\
\text { passado. Na investigação científica, os fósseis são muito importantes. Eles são } \\
\text { vestígios deixados em rochas por seres vivos que morreram há muito tempo. } \\
\text { Quanto a Lamarck, o autor do livro diz que em } 1809 \text { Lamarck sugeriu a } \\
\text { explicação para as evidências em fósseis; seria a evolução ao longo de muitas } \\
\text { gerações. } \\
\text { Escreve: Usando esse raciocínio, Lamarck explicou a existência do longo } \\
\text { pescoço das girafas. Elas seriam descendentes de ancestrais com pescoço curto, } \\
\text { que, buscando alcançar as folhas altas, teriam passado a vida toda tentando } \\
\text { esticar o pescoço, conseguindo torná-lo um pouco mais longo. Ao longo de } \\
\text { milhares de gerações, elas já teriam um pescoço significativamente mais } \\
\text { comprido. }\end{array}$ & $\begin{array}{l}\text { Evolução linear, } \\
\text { analogia da } \\
\text { escada. } \\
\text { Uso do tempo } \\
\text { histórico das } \\
\text { gerações de } \\
\text { família como } \\
\text { analogia para o } \\
\text { tempo biológico. }\end{array}$ \\
\hline
\end{tabular}




\begin{tabular}{|c|c|c|}
\hline 8 & $\begin{array}{l}\text { No capítulo "Evolução" opõe Lineu e o fixismo à noção de evolução orgânica } \\
\text { ou biológica. } \\
\text { De acordo com a evolução, os seres vivos atuais, tanto as plantas como os } \\
\text { animais, são descendentes modificados das plantas e dos animais que viveram } \\
\text { em épocas passadas. Portanto, cada espécie atual, adaptada ao seu ambiente, é } \\
\text { resultado de uma longa história evolutiva, cujo início é desconhecido e } \\
\text { enigmático. } \\
\text { É importante que se estabeleça uma distinção entre o conceito de evolução e o } \\
\text { desenvolvimento orgânico. O desenvolvimento do organismo refere-se às } \\
\text { mudanças que o indivíduo sofre no decorrer de sua vida, passando pelos } \\
\text { diversos estágios do crescimento, amadurecimento sexual, reprodução, } \\
\text { senilidade e morte. Compreende o ciclo vital do organismo e é uma seqüência } \\
\text { de fases numa ordem definida. } \\
\text { A evolução refere-se às mudanças que as populações ou as espécies sofrem no } \\
\text { decorrer do tempo, que conduzem à extinção ou adaptação delas ao ambiente, } \\
\text { por força da seleção natural. } \\
\text { Considera-se uma população ou espécie adaptada quando ajustada, } \\
\text { acomodada e harmonizada com o meio ambiente. }\end{array}$ & $\begin{array}{l}\text { Aborda os } \\
\text { conceitos de } \\
\text { evolução e } \\
\text { desenvolviment } \\
\text { o orgânico sem } \\
\text { os argumentos } \\
\text { de Darwin e } \\
\text { Haeckel } \\
\text { necessários para } \\
\text { esta questão. } \\
\text { Remete à noção } \\
\text { de evolução } \\
\text { harmoniosa da } \\
\text { natureza de } \\
\text { Lamarck. Não é } \\
\text { a definição de } \\
\text { Darwin. }\end{array}$ \\
\hline 9 & $\begin{array}{l}\text { Enquanto Lamarck afirmava que a girafa, ao longo de gerações, aumentava seu } \\
\text { pescoço de tanto esticá-lo, Darwin sentenciava que o ser humano e o macaco } \\
\text { provinham de um único ancestral, chicoteando contra o amor próprio da } \\
\text { humanidade um duro, mas necessário, golpe pelo qual levará tempo até que } \\
\text { seja completamente perdoado. Ambos desafiaram o pensamento predominante } \\
\text { de que as coisas são imutáveis. E, de modo diverso, ousaram dizer que a vida é } \\
\text { o resultado de um longo e contínuo processo de evolução. } \\
\text { Formulou a hipótese de que as formas mais evoluídas surgiam das mais } \\
\text { simples por meio de progressão. } \\
\text { A sua teoria estava baseada na suposição de que os órgãos tornam-se mais } \\
\text { fortes ou mais fracos, mais importantes ou menos importantes pelo uso e } \\
\text { desuso. Quando é pouco utilizado, um órgão tende a desaparecer; ao contrário, } \\
\text { quanto mais utilizado, mais desenvolvido se torna. Além disso, ele admitia que } \\
\text { a evolução fosse decorrente nas espécies e, sob essa influência, as modificações } \\
\text { adquiridas seriam transmitidas aos descendentes. } \\
\text { Lamarck fundamentou, então, sua teoria no uso e desuso e na transmissão dos } \\
\text { caracteres adquiridos. Segundo ele, por exemplo, o pescoço das girafas tornou- } \\
\text { se mais comprido à medida que elas necessitavam esticá-lo para alcançarem os } \\
\text { galhos mais altos das árvores. Essa característica, obtida pelo uso freqüente } \\
\text { dessa parte do corpo, foi transmitida a seus descendentes. }\end{array}$ & $\begin{array}{l}\text { Toma o exemplo } \\
\text { do pescoço da } \\
\text { girafa como a } \\
\text { teoria da } \\
\text { evolução de } \\
\text { Lamarck. } \\
\text { Reforça a } \\
\text { evolução como } \\
\text { progresso, } \\
\text { analogia } \\
\text { criticada por } \\
\text { Darwin. } \\
\text { Analogia da } \\
\text { escada. }\end{array}$ \\
\hline 10 & $\begin{array}{l}\text { Os primeiros seres vivos surgiram na Terra há mais de } 3,5 \text { milhões de anos e, } \\
\text { como uma gigantesca "árvore", vêm evoluindo e soltando numerosos ramos, } \\
\text { que constituem os grupos de seres vivos atuais. }\end{array}$ & $\begin{array}{l}\text { Analogia da } \\
\text { árvore em um } \\
\text { tempo linear. }\end{array}$ \\
\hline 11 & $\begin{array}{l}\text { A teoria da evolução explica como os seres vivos se transformam, adaptando- } \\
\text { se ao ambiente em que vivem e originando novas espécies. Segundo Jean- } \\
\text { Baptiste Lamarck (1744-1829), as transformações das espécies dependeriam de } \\
\text { dois fatores fundamentais, enunciados por ele como leis do mecanismo de } \\
\text { evolução. A primeira é a lei do uso e desuso dos órgãos, e a segunda é a lei da } \\
\text { herança dos caracteres adquiridos. } \\
\text { (...) assim a girafa atual teria surgido de animais com pescoços menores, o } \\
\text { pescoço aumentaria de tamanho. }\end{array}$ & $\begin{array}{l}\text { Toma o exemplo } \\
\text { do pescoço da } \\
\text { girafa com a } \\
\text { teoria de } \\
\text { Lamarck. } \\
\text { Analogia da } \\
\text { escada. }\end{array}$ \\
\hline 12 & $\begin{array}{l}\text { Cientistas supõem que a evolução do ser humano seja da mesma época da dos } \\
\text { gorilas, chimpanzés e orangotangos. Esses animais e os seres humanos } \\
\text { primitivos teriam surgido a partir de ancestrais comuns desaparecidos há cerca } \\
\text { de } 30 \text { milhões de anos. Entre os seres vivos que existem hoje, os que mais se } \\
\text { assemelham ao ser humano são os orangotangos, gorilas e chimpanzés. Eles } \\
\text { podem ficar em pé, eretos, como nós. Mas nenhum deles pode manter-se assim } \\
\text { por muito tempo. Apenas nossos antepassados primitivos desenvolveram a } \\
\text { habilidade de caminhar sobre dois pés, sem o auxílio das mãos e com a face } \\
\text { erguida. }\end{array}$ & $\begin{array}{l}\text { Propõe uma } \\
\text { idéia de árvore, } \\
\text { mas na } \\
\text { explicação } \\
\text { retorna à } \\
\text { analogia da } \\
\text { escada. }\end{array}$ \\
\hline
\end{tabular}




\section{RESULTADOS E CONCLUSÕES}

\section{Análise dos argumentos dos livros didáticos}

Nos 12 livros analisados, as lições sobre evolução são uniformes. Os mesmos argumentos traduzem aos professores e aos seus alunos a noção de evolução com a analogia de escada; trata-se de demonstrar a evolução ao longo do tempo ${ }^{1}$ ou ao longo das gerações como dizem os autores dos livros, de uma escada menor para a maior. $\mathrm{O}$ que aparece são imagens de seres enfileirados, o antecessor gerando o sucessor. Cada novo ser nasce do ser preexistente, melhor e mais complexo, ou pelo menos em pé quando se trata do homem.

O tempo para os autores dos manuais é algo que aparece como uma entidade à parte, pela qual passam os seres vivos. "Ao longo do tempo", de um tempo linear, os animais e plantas passam em um túnel, o do tempo, como determinante da evolução, mas é um tempo genérico, sem os aspectos geológicos e biológicos. Os autores dos textos falam em evolução em um tempo lento e gradual. É claro que o tempo é uma dimensão da evolução, mas escadas não representam a trilha desse tempo quando se trata da evolução, nem esse tempo é aceito como lento e gradual entre os paleontólogos. No caso da evolução humana a metáfora da escada, como vemos, controla o argumento nos livros didáticos, e, como diz Gould (1987), controla o pensamento humano. A analogia da escada mostra que “temos procurado uma única e progressiva seqüência que ligue o símio ancestral ao homem moderno, através de uma transformação contínua e gradual. O elo que falta poderia ser chamado o degrau que falta" (Gould, 1987, p. 50).

A metáfora da escada ignora a riqueza da história humana dada pelas descobertas paleontológicas. Pelas descobertas de Louis e Mary Leakey e o filho deles, Richard Leakey, temos três linhagens diferentes de pré-humanos vivendo contemporaneamente. Em 1975, na Tanzânia, África, quando Mary Leakey descobriu fósseis de Homo, pôde levantar que esse pré-humano e o Australopithecus boisei tenham vivido contemporaneamente. O Homo é considerado descendente direto do Australoptithecus. Já em 1950, Mary Leakey havia descoberto restos fósseis do A. boisei; essa descoberta fez com que fossem admitidas duas espécies australopitecinas vivendo na mesma época. Em 1964, Louis Leakey e seus

\footnotetext{
1 Stephen Jay Gould e Niles Eldredge propuseram, na década de 70, a hipótese de equilíbrio pontuado que preconiza que a evolução ocorre em saltos relativamente rápidos, de cerca de 10 mil anos e, depois, as espécies tendem a se manter constantes por até milhões de anos.
} 
colegas, no leste da África, classificaram uma nova espécie, o Homo habilis, mais tarde considerado como contemporâneo das duas espécies australopitecinas. Ou seja, o Homo é tão antigo quanto o Australopithecus (Gould, 1987).

A analogia da escada sustenta a idéia de evolução linear, na qual de um ancestral pré-humano surgem, um a um, humanóides mais aprimorados. A evolução em escada tira da evolução apresentada por Lamarck, Darwin e Haeckel, no século XIX, seus argumentos centrais:

1) Não há uma seqüência evolutiva para a descrição das espécies vivas como mostram os manuais didáticos. Há seqüências evolutivas elaboradas a partir dos fósseis e do tempo geológico, ou como diz Gould (1987), de trilhas labirínticas, construídas ramo a ramo de uma árvore cuja linhagem sobrevivente está no topo. A seguir mostramos duas imagens; ambas cumprem função cognitiva. A figura 1, do livro didático analisado (número 6), e a figura 2, aceita como a mais verossímil entre os paleontólogos.

\section{Figura 1}

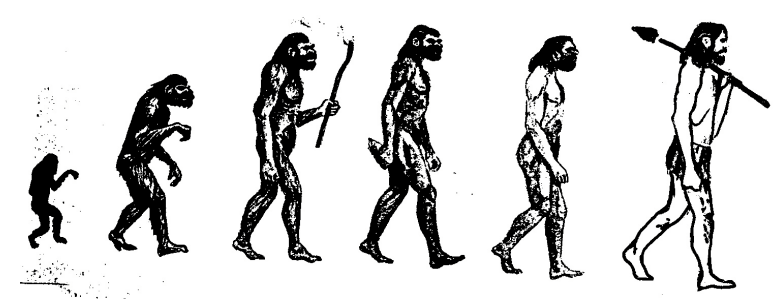

Figura 2

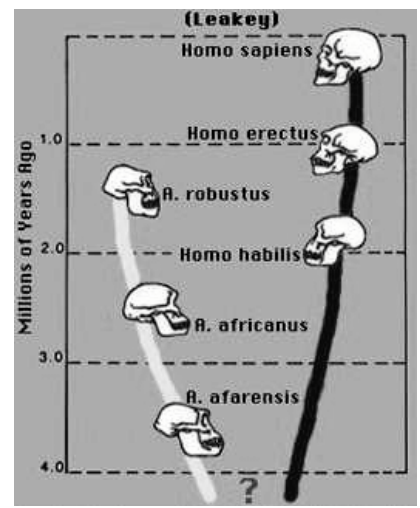

Fonte: www.laser.com.br/usuarios/svasques/evolution.jpg 
2) Provavelmente, ocorreu especiação nestes ramos, ou seja, muitas espécies novas apareceram de ramos que ficaram isoladas geograficamente.

Como se dá a especiação? Isso é um eterno pomo de discórdia, mas a maioria dos biólogos endossaria a "teoria alopátrica" (o debate centra-se na admissibilidade de outros meios; quase todos concordam que a especiação alopátrica é a mais comum). Alopátrica significa "em outro lugar". Na teoria alopátrica, popularizada por Ernst Mayr, as novas espécies surgem em populações muito pequenas, que ficam isoladas do grupo que thes deu origem, na periferia da esfera ancestral. A especiação nessas ilhas isoladas é muito rápida, em termos de padrões evolutivos centenas de milhares de anos (um microssegundo geológico).

Nessas pequenas e isoladas populações podem ocorrer importantes mudanças evolucionistas. A variação genética favorável pode espalhar-se entre eles. Além do mais, a seleção natural tende a ser intensa em áreas geograficamente marginais, onde espécies mal se consolidam. Em grandes populações centrais, por outro lado, as variações favoráveis espalham-se muito devagar, e grande parte das mudanças sofre resistência por parte da população bem adaptada. Ocorrem, claro, pequenas mudanças para fazer face às exigências da vagarosa alteração do clima, mas as grandes reorganizações genéticas quase sempre ocorrem em pequenas populações perifericamente isoladas, que formam, então, novas espécies. (Gould, 1987, p.54)

3) O Homo sapiens não é o produto de uma escada que desde o início até os dias atuais sobrevive em direção ao degrau maior. "Constituímos tão somente a ramificação sobrevivente de um arbusto outrora exuberante" (Gould, 1987, p. 55).

Além do tempo linear e a analogia da escada, os textos didáticos tomam Lamarck e Darwin como os mentores do termo evolução. Nem um nem outro usaram o termo evolução, pois era uma noção muito complicada para a época; evolução pressupunha significados ligados à noção preformista ${ }^{2}$. Lamarck utilizou o termo transformismo e Darwin usou o termo descendência por modificação. A palavra evolução vem do latim evolvere e era a base da teoria do biólogo alemão Albrecht Von Haller que elaborou a teoria de que os embriões se desenvolviam a partir de homúnculos pré-formados no óvulo ou esperma; os embriões evoluíam ou desenrolavam-se (evolvere). Tinha o sentido de progresso, noção que Darwin sempre combateu; a descendência por modificação ou evolução, em sua teoria, não afirmava que existia alguém superior e algo inferior. Tampouco afirmou que a adaptação significava que um ser vivo era melhor que outro.

2 Ver no livro Darwin e os grandes enigmas, de Stephen Jay Gould, o capítulo Acerca de heróis e de tolos na ciência, no qual o autor apresenta os preformistas como cientistas cuidadosos e diz que eles nunca acreditaram no homúnculo como muitos livros dizem. 
Lamarck também não usou o termo evolução; para ele as espécies eram capazes de mudar. Em sua vida, interessou-se pela geologia, climatologia, botânica e zoologia. Cunhou o termo biologia propondo-a como área do estudo dos seres vivos que não poderia prescindir da união da geologia e climatologia para entender as plantas e os animais. Lamarck trabalhou em duas frentes científicas: a de elaborar uma história da natureza e a de trabalhar para a constituição da biologia com método. Em seus trabalhos de taxonomia, esforçou-se para encontrar metodologias adequadas para descrever o conhecimento sobre o mundo natural. Criou modelos e analogias para ir além do método de classificação da época que se detinha na descrição das partes de uma planta ou animal, propondo o uso da dedução. Queria ampliar o campo de atividade científica e construir um modelo de processo natural (Jordanova, 1990).

Nos textos didáticos, o nome de Lamarck está, invariavelmente, ligado ao conceito de herança dos caracteres adquiridos. Não foi uma idéia original de Lamarck; era uma idéia de muitos nos séculos XVIII e XIX, quando a genética ainda não havia explicado os processos de transmissão de caracteres dos seres vivos às gerações futuras.

Lamarck foi, por mais de 40 anos, um homem ativo. Estudou as plantas, os animais, os fósseis, a relação mente-corpo, o papel do comportamento dos animais nas mudanças e na adaptação ao meio ambiente; buscou sempre uma linguagem adequada para expressar os pontos de vista científicos. Trabalhou no Museu Nacional de História Natural de Paris, atendendo e dando aulas a jovens sobre história da natureza e taxonomia. Para este trabalho recebeu o apoio de Buffon. Suas obras são importantes pelo esforço em relacionar a química e a física do ambiente com as plantas e os animais, que resultou na teoria sobre o transformismo das espécies. Para descrever suas idéias fez um grande trabalho metódico para a explicação dos fenômenos naturais e, para isso, era rigoroso nos detalhes e tecia muitas analogias (Jordanova, 1990).

Em sua obra, síntese de anos de estudo, observação e classificação Filosofia Zoológica -, publicada em 1809, pode-se ler a noção de transformismo como trocas contínuas de adaptação e equilíbrio harmônico na natureza (Jordanova, 1990). A hipótese central de Lamarck era a de que o ambiente exercia pressões sobre os seres vivos. Elaborou, assim, as hipóteses de que os seres vivos poderiam dar respostas a essas pressões se adaptando ao ambiente. O corpo manifestaria mudanças sob essas pressões, utilizando algumas partes mais do que outras. Nesse contexto de análise das mudanças, surge a noção do uso e desuso. Essas mudanças seriam transmitidas para os descendentes; uma idéia bastante plausível no século XVIII e início do XIX, antes da teoria de Mendel. 
No entanto, dessa riqueza de vida e de ciência dos séculos XVIII e XIX, os autores dos textos didáticos passam de geração a geração, contando uma história - a do pescoço das girafas - periférica da história do debate evolucionista.

$\mathrm{Na}$ história de Lamarck, a alusão ao pescoço das girafas está presente, de modo breve, em um parágrafo de sua obra magna Filosofia Zoológica. Nela apresentou, de modo mais profundo, a idéia de mutação das espécies, incluindo seu grande interesse: os fósseis. Dos inúmeros exemplos animais que ele descreveu, o da girafa não tem a importância que os livros lhe dão. Mas por que a lei do uso e desuso está presente nos livros, tratando somente do pescoço das girafas? Por que os crustáceos, os insetos, os fósseis, as plantas analisadas por Lamarck perdem lugar para um comentário breve e sem detalhes?

Jordanova (1990) diz que Lamarck foi o primeiro naturalista que ofereceu um panorama sistemático do desenvolvimento histórico da natureza. Tentava demonstrar que o passado continuava no presente, e para comprovar que as formas naturais se transformam dedicou sua vida aos estudos da geologia, zoologia, metereologia, química e psicologia. Anotava muitos aspectos da natureza e, às vezes, incluía um exemplo sem citar a fonte de sua leitura. O pescoço das girafas atraiu muitos leitores, mas apenas depois do debate de St. Georges Mivart e Darwin em 1871 e 1872.

O pescoço das girafas tornou-se pop star das lições de evolucionismo após o debate entre o antievolucionista Georges Mivart e Darwin. Roque (2002) relata o contexto do debate, trazendo inúmeros trabalhos sobre a origem da história mal contada do pescoço das girafas. Um deles é o ensaio de Stephen Jay Gould, The Tallest Tales, de 1996. Outra pesquisa que Roque (2002) apresenta contra a desmoralizante e a falsa história do pescoço das girafas é a dos zoólogos Robert Simmons, Lue Scheepers e a do professor de evolução Steve Rissing.

O embate de Mivart e Darwin começou com a publicação do livro Origem das Espécies em 1859. Nessa edição, ele faz referência à cauda da girafa. Em 1871, Mivart publicou uma crítica a Darwin no texto The genesis of species; nesse ensaio, Mivart concentrou-se na discussão sobre as afirmações relativas ao pescoço das girafas, em uma linguagem sarcástica. Em 1872, na última edição de Origem das Espécies, Darwin escreveu um capítulo sobre o exemplo que gerou debates (Roque, 2002). Foi assim que a história das girafas surgiu. De um modo ou de outro, prevaleceu o argumento de que Lamarck foi o autor da lei do uso e desuso e das folhinhas do alto das copas das árvores, gerando a seleção de girafas com pescoço longo. Nesse ponto, podemos dizer que as editoras de livros 
didáticos são pródigas em imagens. A maioria deles usa o carimbo com o desenho das girafas comendo as folhas mais altas das árvores. É a lei do uso e do abuso da história antievolucionista.

O pescoço das girafas ou "torre de observação", com que a girafa pode controlar a aproximação de predadores, tem mais histórias, desta vez mais verossímeis, relatadas por Simmons e Sheepers no artigo Winning by a nek: sexual selection in the evolution of giraffe (Vencendo por um pescoço: seleção sexual da girafa), de 1996 (Roque, 2002). Para os dois zoólogos, o pescoço comprido seria resultado da correlação genética entre os sexos e da observação do ambiente. Na disputa pelas fêmeas os machos lutam e o pescoço é parte desse duelo que levam, inclusive, à morte do perdedor.

As observações de Simmons e Sheepers mostraram que na estação seca as girafas alimentam-se de arbustos, ou seja, dobram o pescoço para comer. Na estação das chuvas, elas se alimentam das folhas em copas mais altas. Não há relação do pescoço com a altura das folhas nas árvores.

Outro aspecto observado por Simmons e Sheepers é que as fêmeas passam metade de seu tempo alimentando-se com o pescoço em posição horizontal (comportamento tão típico que é útil para identificar o sexo do animal à distância). Além disso, ambos os sexos alimentam-se mais freqüentemente com o pescoço curvado para baixo. Tudo isso, segundo eles, sugere que o tamanho do pescoço não teria evoluído especificamente em decorrência da busca de alimento em locais mais elevados. Para refutar a possivel objeção de que a competição entre os machos não explicaria o comprimento do pescoço das fêmeas, Simmons e Sheepers argumentam que ele seria resultado da correlação genética entre os sexos, e que outras espécies exibem correlações similares entre sexos - ou seja, no caso das fêmeas, o pescoço longo teria vindo como uma espécie de "brinde". (Roque, 2002)

Steve Rissing (2001, apud Roque, 2002), professor de evolução e ecologia, na Universidade Estadual de Ohio, EUA, diz que o "conto" das girafas faz parte das preferências dos cartunistas de Noé e defende que a tese de seleção sexual e não seleção natural não invalida a teoria darwinista, pois é também um mecanismo de evolução dos seres vivos (Roque, 2002).

\section{As figuras argumentativas da retórica pedagógica: analogias preformistas para a explicação da evolução de Lamarck e Darwin}

Pela exposição que fizemos até aqui, podemos ver que as questões sobre evolução são ricas e densas; os argumentos de Darwin e de Lamarck mantêm-se atuais em um século em que a genética colabora mais para a densidade da evolução. Entretanto, os manuais de ciências fazem uma 
opção por argumentos "didáticos", opção essa que significa, em outras palavras, reduzir as metáforas e os modelos das ciências, as noções constitutivas das teorias evolucionistas por metáforas, e/ou as noções pedagógicas não mais das teorias, mas dos elementos periféricos do discurso científico. No caso de Lamarck, esse movimento didático omite dos leitores - alunos e professores - a verdadeira teoria do transformismo e oficializa, nas palavras de Roque, uma versão fácil, "pedagógica", que ridiculariza e desmoraliza o naturalista.

Os textos didáticos analisados, embora recentes, trazem as mesmas lições de décadas passadas. Alguns inovam essas lições, trazendo citações/cabeçalhos de Edgar Morin, por exemplo, mas mantêm as velhas histórias que não são as histórias dos métodos e das ciências da evolução.

As figuras argumentativas não mais carregam o leitor ao universo cognitivo das teorias evolucionistas e permitem abertura ao mundo científico; ao contrário, em nossa opinião, a adesão às lições evolucionistas dos textos didáticos é passageira e endossa os argumentos criacionistas, pois:

a) Tratam de um tempo linear sem história geológica, biológica e humana. Todos - rochas, animais, plantas e o homem - vivem em um mesmo túnel do tempo. A expressão "ao longo do tempo" é corrente nos livros analisados e joga com a abstração das observações dos fósseis, com os argumentos baseados nas evidências empíricas, tão caras à biologia evolucionista. $\mathrm{O}$ argumento temporal, nesse caso, atende a noção de "design inteligente", o criacionismo moderno, isto é, "ao longo do tempo", as formas e a fisiologia dos seres vivos se aprimoram. Nada mais preformista, criacionista do que o ícone tão propalado representando a evolução (linear, em escada) do macaco ao Homo sapiens.

b) Descrevem, no caso de Lamarck, uma suposta teoria, supostas leis (transmissão dos caracteres e do uso e desuso), a partir de um único exemplo que se transforma em modelo novamente.

c) Abandonam a riqueza dos detalhes observados por Lamarck e Darwin e a construção metodológica que estes teceram para dar as explicações teóricas pela generalização das idéias sobre evolução tais como: "os homens atuais são descendentes modificados de nossos antepassados"; "supõe-se que a evolução do chimpanzé, dos gorilas e orangotango tenha surgido na mesma época que a dos homens". Há dois movimentos mentais que invertem as teorias, no caso de Lamarck e Darwin: a primeira é desconhecer as teorias, suas hipóteses, suas 
evidências empíricas e a construção das analogias que sustentam a teoria. A segunda é tomar os exemplos dessas grandes teorias (que, no caso, são partes das evidências empíricas), como a própria teoria. As generalizações presentes nos livros didáticos não são, para nós, deduções, mas, sim, argumentos pedagógicos que pretendem apresentar a teoria, seu vocabulário, seus conceitos, sem a teoria. O resultado, mais uma vez, é uma teoria evolucionista tornada criacionista.

Contenças (1999) afirma que as metáforas presentes nos livros didáticos são excessivas. Isso pode ocorrer no caso da genética. $\mathrm{Na}$ análise dos manuais brasileiros, temos, no quadro que diz respeito à evolução, um discurso que utiliza a técnica de apresentar argumentos por exemplos, e a situação retórica, nesse caso, impede o acesso dos leitores (auditório, professores e alunos) aos fundamentos da teoria evolutiva. Não há excessos de metáforas, mas, sim, a redução das analogias elaboradas por Lamarck e Darwin; nos textos didáticos de ciências, efetivamente, temos a redução das boas metáforas em prol de exemplos inconsistentes que não cabem para os modelos teóricos de Lamarck e Darwin. O resultado disso é que não vamos precisar de conflitos pedagógicos contra alguns representantes políticos e religiosos (alguns, como no caso do Rio de Janeiro, já oficializaram o criacionismo nas escolas), pois os livros didáticos quando trabalham o tema Evolução, traduzem o preformismo do século XVII e XVIII e, de quebra, trazem o "design inteligente" como teoria adjacente.

Respondendo, então, à pergunta feita na introdução deste artigo, diremos que a passagem das ciências para os livros didáticos é feita em versão anticientífica, com modelos inconsistentes e com vocabulário reducionista, que provoca uma adesão imediata à teoria, mas esmorece em seguida, pois não permite novas aberturas para a compreensão de fenômenos evolutivos.

\section{LIVROS DIDÁTICOS ANALISADOS}

Livro 1: PAULINO, Wilson Roberto. Biologia Atual. 10. ed. São Paulo: Ática, 1998. v. 3.

Livro 2: BARROS, Carlos; PAULINO, Wilson Roberto. Os seres vivos. 60.ed. São Paulo: Ática, 1999. Volume voltado para a $6^{\mathrm{a}}$ série.

Livro 3: SOARES, José Luis. Fundamentos de biologia. São Paulo: Scipione, 1998. 
Livro 4: LOPES, Sônia. Bio. Volume único completo e atualizado. 11. ed. São Paulo: Saraiva, 2000.

Livro 5: CRUZ, Daniel. Ciência e Educação Ambiental. 2. ed. São Paulo, 2004.

Livro 6: CARDOSO, Alcina Maria de Souza; GONÇALVES, Heitor Antonio; CARDOSO, Marcos Antonio Benigno. Ciências da Escola para a Vida. Belo Horizonte: Editora Lê, 1996.

Livro 7: CANTO, Eduardo Leite. Ciências naturais. Aprendendo com o cotidiano. São Paulo: Moderna, 1999.

Livro 8: DIAS, Diarone Paschoarelli. Biologia Viva. São Paulo: Moderna, 1996.

Livro 9: CHEIDA, Luiz Eduardo. Biologia Integrada. São Paulo: FTD, 2002.

Livro 10: FAVARETTO, José Arnaldo; MERCANDANTE, Clarinda. Biologia. São Paulo: Moderna, 1999.

Livro 11: LINHARES, Sérgio; GEWANDSZNAJDER, Fernando. Biologia (Programa completo). São Paulo: Ática, 1999.

Livro 12: OLIVEIRA, Nyelda Rocha de; WYKROTA, Jordelina Lage Martins. Ciências: descobrindo o ambiente. Formato Editorial, 1991.

\section{REFERÊNCIAS BIBLIOGRÁFICAS}

BIZZO, Nélio. Graves erros nos livros didáticos de ciências. Ciência Hoje. São Paulo: Sociedade Brasileira para o Progresso da Ciência, v. 21, n. 121, jun. 2000.

BRETON, Philippe. A argumentação na comunicação. Bauru: EDUSC, 1999.

CHALMERS, Alan. O que é ciência, afinal? São Paulo: Brasiliense, 1993.

CONTENÇAS, Paula. A eficácia da metáfora na produção da ciência: o caso da genética. Lisboa: Editora Instituto Piaget, 1999.

GOULD, Stephen Jay. Darwin e os enigmas da vida. São Paulo: Martins Fontes, 1987. 
JORDANOVA, L. J. Lamarck. México: Fundo de Cultura Econômica, 1984.

KENSKI, Rafael. O que há de errado com Darwin? Revista Super Interessante. São Paulo: Abril, v. 15, n. 8, ago. 2001. p. 70-75.

KLYCE, Brig. The tree of life. Disponível em: www.panspermia.genetree. gif.arquivos $\backslash$ tree.htm. Acesso em: 30 jun. 2005.

KORTHOF, Gert. Stephen Jay Gould as a critic of orthodox neo-darwinism. Disponível em: www.home.wxs.nl/ gkorthof/korthof63.htm. Acesso em: 30 jun. 2005.

MAZZOTTI, Tarso Bonilha; OLIVEIRA, Renato José. A retórica das teorias pedagógicas: uma introdução ao estudo da argumentação. Caxambu, 26 a 30 de setembro de 1999. Apresentado em: Reunião Anual da Anped, 22.

. Ciências da Educação. Rio de Janeiro: DP\&A, 2000.

OLIVEIRA, Daisy Lara. O antropocentrismo no ensino de ciências. Revista Espaços da Escola. Unijui: Livraria Editora Unijui, v. 1, n. 4, p. 8-15, abr./jun. 1992.

OLIVEIRA, Renato José de. De romances e solilóquios. Revista Espaços da Escola. Unijui: Livraria Editora Unijui, v. 1, n. 4, p. 16-22, abr./jun. 1992.

PÉREZ DE EULATE, Lourdes; LLORENTE, Enrique; ANDRIEU, Amaya. Las imágenes de digestión y excreción en los textos de primaria. La Enseñanza de las Ciências, v. 2, n. 17, p. 165-178, 1999.

POLLACK, Robert. Signos da vida: a linguagem e os significados do ADN. Rio de Janeiro: Rocco, 1997.

PRETTO, Nelson de Luca. A Ciência nos Livros Didáticos. Campinas: Unicamp; Bahia: Universidade Federal da Bahia, 1985.

ROQUE, Isabel Rebelo. Sobre girafas, mariposas, corporativismo científico e anacronismo didático. 2 de setembro de 2002. Disponível em: www.lainsignia.com. Acesso em: 10 maio 2005. 


\section{Agradecimentos}

Para a elaboração deste artigo tive a colaboração da acadêmica Mariana Gomes Clemente, aluna do Curso de Ciências Biológicas da Universidade Estadual de Maringá, Paraná, que selecionou o material didático para análise.

Agradeço a Isabel Rebelo Roque. Embora eu não a conheça pessoalmente, seu material foi muito importante para meu projeto de análise de livros didáticos e para este artigo em especial. Após ter finalizado o artigo, comuniquei-me com ela, via internet, que o leu e enviou algumas sugestões.

Recebido em: agosto 2005

Aprovado para publicação em: novembro 2005 